\title{
Clothing the postcolonial body: art, artifacts and action in south eastern Australia ${ }^{1}$
}

\author{
By Sylvia Kleinert
}

Sylvia Kleinert is Adjunct Associate Professor at the Australian National University and Charles Darwin University. Her research addresses questions related to Indigenous cultural production.

\begin{abstract}
In this paper I explore the significance of dress as an expressive and performative genre within contemporary art in south eastern Australia. My aim is to build on and expand recent studies in cross-cultural discourse to offer a broader, more inclusive framework for contemporary art practice in the south east grounded in dynamic Aboriginal cosmologies that demonstrate both continuity and innovation. Specifically I will examine two arenas of practice usually treated as separate domains: the revitalization of fibre seen in shell necklaces, baskets and possum skin cloaks - once worn or carried on the body - and the appropriation by artists of items of colonial and contemporary dress such as blankets, trousers, knitwear and T-shirts. My research reveals how art, as a form of action, contributes to social and cultural sustainability by engaging with an Aboriginal landscape and a postcolonial world to imagine 'cultural futures.'
\end{abstract}

\section{Paper}

The dramatic events of February 2008 when Ngambri/Ngunnawal elder Matilda House, dressed in a possum skin cloak performed the first Indigenous 'Welcome to Country' for the opening of the Australian Parliament in Canberra and then Prime Minister Kevin Rudd apologised to the Stolen Generations, provides a key starting point for this discussion on the significance of dress in the expression and performance of Aboriginality. In recent years contemporary audiences have become increasingly familiar with these forms of cultural practice taking place across a wide range of venues in conjunction with cultural tourism, exhibition openings in galleries and museums and events such as the 2000 Sydney Olympics. As such these cultural performances provide important settings for the contemporary circulation and renegotiation of Indigenous identities (Myers, 1994). For Indigenous performers and audience participants alike this 'culturemaking' (Myers, 1994) will inevitably be fraught with contradictions and ironies.

1 An earlier version of this paper was presented at the Selling Yarns conference National Museum of Australia 6-9 March 2009. Germane to this paper is also a paper on' Aboriginal dress in south east Australia' by the author in the Encyclopeadia of world dress and fashion, Berg (2010). 
Nevertheless, by choosing to participate in these events on their own terms, Aboriginal Australians demonstrate the degree to which they understand and appreciate how to manipulate representations to their own advantage.

In recent studies by Maynard (2000a, 2002) and Craik (1994) dress has emerged as central to understanding how clothing 'as the private made public' is pivotal to the formation of individual and group identity. Dress, it is argued, has left behind its earlier association with fashion to assume greater complexity in relation to broader global concerns that encompass ethnic and cultural identities. In her research, Maynard (2002) has productively contrasted the colonial provision of government blankets - initially as a form of conciliation - with the performative use of T-shirts in public protests as a public assertion of Aboriginal identities. It becomes clear that, for an ethnic minority entangled in the uneven power relationships of a settler society, the visibility politics of clothing is crucial to understanding the representation of Aboriginal identities within the wider framework of nation state.

Aboriginality itself is crucial to this debate. Once defined in fixed essentialising terms, cultural identity is today seen as "subject to the continuous "play" of history, culture and power' (Hall, 1990, p 225). Identity in this sense is 'a matter of "becoming" as well as of "being"' (Hall, 1990, p 225). Thus cultural identity arises from an Aboriginal cosmology that demonstrates both continuity and innovation. In using the term innovation, I am not referring to a modernist aesthetic of originality and individual expression. ${ }^{2}$ Rather, I draw upon recent studies in cross cultural discourse (Morphy, 2008; Dodson, 2003; Glowczewski, 1999; Ginsburg and Myers, 2006) in which Aboriginal cosmologies are defined in terms of continuities and discontinuities: concerned with the future as much as the past (Hall, 1990, p 225). Thus Aboriginal culture follows its own distinctive trajectories (Morphy, 2008), re-connecting with the past and creating new representations, engaged in spiritual, moral and political terms both with an Aboriginal landscape and a postcolonial world. By considering the significance of dress as an expression of identity and difference and as a means of engaging in dialogue with a settler society, this essay argues that the visual politics of clothing offers a broader, more inclusive understanding of contemporary Aboriginal art in south eastern Australia. Specifically it shows how art, as a form of action, contributes to social and cultural sustainability by reconnecting with the past and resignifying in a postcolonial world to imagine cultural futures (Ginsburg \& Myers, 2006)

2 Morphy (2008, p 194) argues that accepting Aboriginal art as Indigenous modernism imposes constraints which set Aboriginal art on an alternative trajectory determined by the modernist concern with innovation and originality. When Aboriginal art is celebrated for its hybridity, this redirects the interpretation of Aboriginal art away from its own Indigenous trajectory. 


\section{Postcolonial bodies}

Dress carries particular resonance in south eastern Australia where two centuries of colonisation have impacted on Aborigines. In the south east Aboriginal Australians were subject to unrelenting colonisation, devastated by disease and violence, dispossessed from traditional lands and relegated to remote missions and reserves. With colonisation Europeans brought their own understandings of dress as part of the civilizing process of modern society: the adoption of clothing codes was linked to class, gender and social mores which they proceeded to impose on Aboriginal people. A crucial aspect of colonisation was the emphasis given to clothing as a mark of civilization. Maynard argues that the 'absence of clothing has been regarded dialectically as a lack of, or sign of, that which exists outside the civilized' (Maynard 2002, p 191). Thus clothing explicitly circulates in the discourses of fear and admiration generated by a primitive Other. To remedy this situation, colonial officials dispensed government clothing with the result that, in the first decades of settlement, traditional clothing had almost completely disappeared. Nevertheless it should not be assumed that the dramatic interventions of colonisation, meant an unequivocal acceptance of European dress. As I discuss elsewhere, what emerges is an uneven and yet complex process of social mediation across various exchange systems where clothing served a range of interpretative possibilities within competing local, cultural and political agendas (Kleinert, 2010)

In reality Aboriginal people in south eastern Australia had long been incorporated within global processes. From the earliest arrival of European explorers, Aboriginal artifacts were traded as part of cross cultural exchange - widely admired and sought after as exotic curiosities. By the mid- nineteenth century the collections amassed by R. E. Johns would eventually be acquired by Museum Victoria, but the basis of these collections was European: Johns sourced objects from other collections, friends and family and salerooms but not directly from Aboriginal people (Griffiths, 1996, pp 28-54; Morphy, 1998, pp 319-320). Hence these artifacts entered museum collections with little understanding of their Indigenous context and their intrinsic value for Aboriginal people. Meanwhile Aborigines continued to produce artifacts such as boomerangs, baskets and possum skin cloaks for exchange and for sale to dealers and tourists. By the late nineteenth century however, anthropologists came to the belief that traditional culture no longer survived in the south eastern Australia and as a consequence, these hybrid objects were dismissed as inauthentic tourist souvenirs (Phillips \& Steiner, 1999; Morphy, 2008).

This study is focused on the contemporary artistic expression which emerged in the south east during the 1970 s and 1980s. With the repeal of discriminatory and oppressive legislation in favour of policies that promoted self-determination, a new Aboriginal art movement emerged in the capital cities inspired by the Black Power movement in Northern America and emerging pan-Aboriginal Land Rights. Lin Onus (1948-1996), who led the genesis of a new Koorie art movement in Melbourne, recalled the 'new class' of Aboriginal people who 
emerged to public attention in the late 1960s: 'Many were young, many were articulate, but they were all angry' (Onus, 1993, p 290). At the time a number of important exhibitions like Koori Art '84 at Artspace in Sydney played a seminal role in bringing artists together. Subsequently Aboriginal controlled organizations began to emerge such as Boomalli Aboriginal Artists Cooperative established in 1987 by a group of young Aboriginal art students to provide a network of support for young artists through a gallery space and exhibitions such as True Colours (1994-5) and Blakness: Blak City Culture (1994-5) which began to redefine Aboriginality.

It was not until the 1980s however that a parallel renaissance occurred among Aboriginal women in the south east. ${ }^{3}$ In the catalogue for the groundbreaking Aboriginal Women's Exhibition in 1991 Indigenous writer Henrietta Fourmile (1991, pp 4-5) identified several reasons for this delay: a patriarchal bias on the part of anthropologists who failed to acknowledge Aboriginal women's complementary role in society; ${ }^{4}$ art/craft debates which relegated women's practice to the anonymous realm of craft and the impact of Aboriginal stereotypes which dismissed Aborigines in the south east as having 'lost' their culture by comparison with 'real' Aborigines in northern Australia. In response, she argued, women preferred to focus on the production of traditional fibre items such as baskets, shell necklaces and printed textiles. ${ }^{5}$ Thus contrasts can be drawn between the tough, oppositional art of the cities where (male) painters predominated $^{6}$ and the revitalisation of an intercultural and collaborative fibre practice through workshops and exchange programs led by senior women located in small, sometimes relatively isolated rural communities. ${ }^{7}$ Indicative of the emerging fine art status of fibre practice is the inclusion of Ngarrindjeri artist Yvonne Koolmatrie's eel traps in Fluent, the 1997 Venice Biennale, alongside the paintings of Emily Kame Kngwarreye and Judy Watson and, in 2005, the

3 Key exhibitions are: Women's art exhibition (1991); Women's Work: Aboriginal women's artifacts in the Museum of Victoria (1992); Tactility: Two centuries of Indigenous objects, textiles and fibre (2003); Twined together: Kunmadj njalehnjaleken (2005); Woven forms: contemporary basket making in Australia, (2005) and Recoil: change and exchange in coiled fibre art (2007).

4 The research of Lesley McCall (1988) confirms the androcentric bias in the Museum Victoria collection.

5 West points out that, in addition to funding from the Aboriginal Arts Board of the Australia Council for the Arts, the Crafts Council of Australia also directed funds toward the development of Indigenous programs and exchanges in Northern Territory, Western Australia and South Australia (2007, p 13)

6 For example in Koori Art '84 of the nineteen 'urban' Aboriginal artists represented only five are women. However these gender distinctions may also be an effect of Western categories. In European art history the category of craft is directly connected with women (Parker 1984) whereas there is ample evidence of men's contemporary and historical involvement in fibre practice (Mellor \& Hamby, 2000; Wood-Conroy, 2000).

7 See, for example, Two Countries: One Weave (1992) which bought together Ngarrindjeri women from the Riverland region of South Australia and women from Maningrida in Arnhem Land (Mellor \& Hamby, 2000, pp 372-373). Exchanges have occurred since through the Batchelor Institute of Indigenous Tertiary Education in Alice Springs, and Tennant Creek and through workshops in the Western Desert and Western Australia (West, 2007, pp 24- 25, 31, 45) 
prizewinning almost life-size Tjanpi Grass Toyota created by women from Blackstone community, Western Australia for the Aboriginal and Torres Strait Islander Art Award.

Recent studies in cross cultural discourse (Morphy, 2008; Myers, 1994; Philips \& Steiner, 1999) have explored the way in which anthropological and art historical categories of art/artifact and art/craft have consistently defined Aboriginal art in European terms. ${ }^{8}$ In charting the shift from primitive art to contemporary Indigenous art, their insights demonstrate the way in which processes of value creation have generated national and international recognition for Aboriginal art. But the problem is that the majority of this writing and related exhibitions is focused on northern Australia - in effect, reinforcing colonial discourses of race and culture (Gibson, 2008; Allen \& Greeno, 2005, p 17). Since the 1970s, the development of acrylic dot painting in Central Australia has contributed to this separation, enhancing the status of Aboriginal art and culture as a unique symbol of national identity. Although the remote/urban dichotomy has been questioned, it is clear that for Aborigines in the south east, the effect and experience of these colonial categories can be internalised as a sense of loss and expressed as a profound ambivalence (Gibson, 2008). ${ }^{9}$ Nevertheless it is important to acknowledge the diversity of Aboriginal experiences in relation to particular geographic, historical and material circumstances and generational differences. We need to acknowledge that Aboriginality proceeds through a complex repertoire of critical strategies and articulations 'at times ancient, at times subversive, at times oppositional, at times secret, at times shifting' (Dodson cited by Grossman 2003, p 5).

This study aims to build on and expand cross cultural discourse in relation to contemporary Aboriginal art in south eastern Australia. In the following section I will begin by examining some of the objects -once worn or carried on the body - produced in the revival of fibre practice before looking at the appropriation of European items of dress by city-based artists. Obviously I in no way suggest that these two strands do justice to the complexity and diversity of contemporary art practice in the south. Rather I argue for a broader, more inclusive understanding of contemporary Aboriginal art in the south east. While each strand appears to be a discrete domain with its own distinctive trajectories, in reality, this separation is the outcome of deeply entrenched Western categories which have served to mask the many commonalities and interconnections -expressive of an integrated and holistic Aboriginal worldview.

8 Morphy (2008, p 12) argues that 'Art as a category is deeply entangled in value creation processes. Since the eighteenth century, the category of fine art has been used to exclude recognition for other art forms.'

9 The loss felt in relation to development is not of course restricted to south east Australia. See Merlan (1989). 


\section{Renewal and revitalisation}

Since the 1970s with the greater freedom offered by policies of self-determination, Aborigines across south eastern Australia embarked on a remarkable process of cultural revival in language, law and culture. Driven by an imperative need to redress a sense of loss and elation at the opportunity to re-engage with the past these cultural revivals have assumed various forms: re-connecting with Country, establishing relationships with remote communities and participating in workshops and exchange programs. Nevertheless there is a sense in which these cultural revivals are frequently misunderstood and may be read by the wider community in potentially damaging ways as a fabrication or an illusion of identity (Gibson, 2008; Kuper, 2003). Therefore there is a pressing need for studies like that undertaken here which examine the way in which cultural revivals proceed. Far from being a mere replication of the past, cultural revivals involve a complex process of recreation and transformation, proceeding by way of memory and history and narratives of identity and experience that carry political, moral and cultural force.

Fibre has always played a central role in the productive activity of Aboriginal Australians. Across the south east, plant and animal-based fibres were spun and coiled into structures that fulfilled a diverse range of functions in both spiritual and material terms.

In many cases items of dress encoded complex meanings as markers of individual identity in relation to social hierarchies, age and gender. For instance, a possum skin cloak used as protection against inclement weather, to carry weapons and for women to carry babies, also served as a marker of individual and group identity. In death, as in life, the individual's possum skin cloak, together with other personal items such as woven baskets, tools and food, ensured a safe return of the spirit to the ancestral domain. Drawings by Wurundjeri artist, William Barak, depict men dancing in ceremony wearing cloaks like a protective mantle accompanied by women seated with clap sticks and possum skin cloaks rolled tightly across their knees as drums. For Aborigines, the creativity and effort involved in the production of these items was invested with intense meanings as part of a hunter-gatherer lifestyle with its own well established exchange relations. Despite the lack of interest on the part of institutions and their exclusion from discourses of Aboriginality, Aborigines in southeastern Australia never ceased to be involved in the cultural production of items such as boomerangs and baskets. Aborigines in the south east express concern with 'keeping culture': in the process of transmitting the knowledge and skills required to gather and prepare materials and create a boomerang or basket, children learn respect for Elders, listen to the stories of their people and gain access to their cultural heritage.

Under the impact of assimilation policies - in place for the better part of the twentieth century - government policies sought to erase cultural life. In relaying their historical experiences Aboriginal people recall being punished for speaking 
language and passing on skills and knowledge. Unsurprisingly many Aboriginal people chose not to pass on their cultural knowledge. Yet Aboriginal culture survived. Gundidjmara woman Connie Hart (1917-1993) recalls that 'No one taught me to make my baskets. I used to watch my mother do it ... My Mum told me that we were coming into the white people's way of living. So she wouldn't teach us' (Griffiths, 1996, pp 279-281). However forty years later, after her mother had died, Connie Hart felt free to make her first basket and later conducted workshops at the Hamilton Keeping Place in western Victoria. Likewise the cultural revival of Ngarrindjeri weaving can be attributed to the initiative of a single custodian, Doreen Kartinyeri (1935-2007) who, in 1982, established workshops at Raukkan (Point McLeay) and Menindie for the Ngarrindjeri of the Lower Murray, the Coorong and Lake Alexandrina region of South Australia. Yvonne Koolmatrie and Ellen Trevorrow attended these workshops and each went on to a distinctive career.

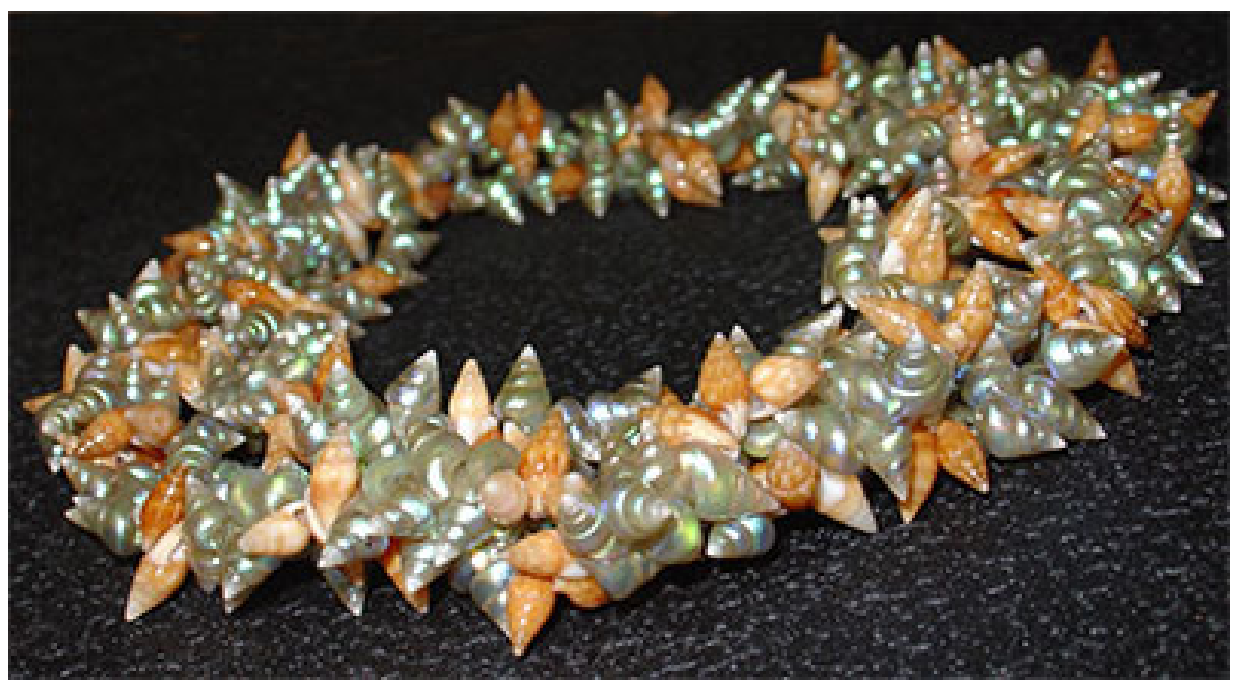

Plate 1: Lola Greeno, Untitled Shell necklace, 2006, maireener and oat shells. $180 \mathrm{~cm}$ in length, Reproduced with permission of the artist

In Tasmania, where Trucanini (Truganini) stands as an ironic symbol of colonial narratives of extinction, the continuous production of shell necklaces is cause for great celebration (Greeno ,2006). (Plate1) Such steadfast cultural continuity in the face of genocide testifies to the resilience of Aboriginal Tasmanians. For women living in exile on Flinders Island, the production of shell necklaces represented an important means of economic survival, sold or bartered to provide food and clothing for their families. Yet, even today, the complex knowledge and skills required to make shell necklaces are tightly held, a precious secret restricted to certain key families and passed down from one generation to another from mother to daughter. Using long strands of up to almost two metres in length, the artists create distinctive patterns from various types of shells collected from different sites. Today the shell necklaces fulfill multiple roles that traverse public and private domains. In homes, necklaces draped over family photographs offer 
a symbol of love and protection; in a public context, they feature in ceremonies, in workshops and in the community festivals putalina and larapuna (Greeno, 2006, p 54). With emerging fine art status, contemporary shell necklaces, whose brilliant shimmer brings comparison with northern Australia (Morphy, 1992), are today highly sought after as prestigious items commissioned by private and institutional collections.

Nevertheless as objects traverse the colonial categories of art/artifact and art/ craft tensions and ambiguities inevitably arise. Lindy Allen and Lola Greeno writing in a catalogue essay for the exhibition Woven Forms: Contemporary Basket Making in Australia, examine the range of productive activity in contemporary fibre practice and its critical response. They draw contrasts between the work of senior custodians, who produce 'cultural pieces' (like the coiled 'sister baskets' unique to the south east) ${ }^{10}$ which may have personal, historical and cultural resonance and the production of individual and expressive objects that are seen to 'push the boundaries of the medium' (Allen \& Greeno, 2005, p 19). ${ }^{11}$ The upshot is that the 'cultural pieces' where the artist has followed historical templates are relegated to the museum while the more individual work is applauded and given considerable recognition as an artwork 'which only ever allows a one-dimensional, aesthetic judgment' (Allen \& Greeno, 2005, pp 20-21). It is clear from this discussion how the value judgments implemented through Western categories and market forces impact on the effect and experience of contemporary fibre practice. But in the process, as Howard Morphy points out (2008, p 194), tradition and innovation are located in opposition, in effect creating two separate categories. ${ }^{12}$ An alternative viewpoint would argue that within Aboriginal cosmology there exists both continuity and innovation. From this perspective both 'cultural pieces' and art works contribute to cultural cohesion and sustainability by rebuilding communities and by gaining recognition for a dynamic and resilient Aboriginal presence. Above all these somatic objects resonate in relation to an Aboriginal landscape in terms of their texture and smell, their connection to people and place and to an ancestral

10 An historical precedence exists for the transfer and exchange of fibre techniques. In 1922 missionary Gretta (Margaret) Mathews, who had previously learned coiling from Ngarrindjeri women, introduced the coiling technique to the Methodist Mission at Goulburn Island (Warruwi) (West, 2007, pp 14-15; Mellor and Hamby 2000).

11 In tracing the history of the efflorescence in fibre art, West observes that support by the Craft Council of Australia focused on 'adapted' craft rather than 'customary' weaving (2007, p 13). It is interesting to note that in Recoil (2007), two of the most innovative fibre artists in the south east are included, but no 'customary' weaving.

12 As Nicholas Thomas argues 'Curators... and anthropologists have become notorious for fetishizing traditional culture to the exclusion of those cultures' historically adapted and innovative expressions' (Thomas, 1999, p 197). Thomas succintly captures the way in which western discourses sustain an apparent opposition between a reified tradition and innovation. He continues: 'The significance and effects of Indigenous art can only be misunderstood if we insist on celebrating either the so-called 'traditionalist' expressions or the 'contemporary' ones instead of acknowledging both' (Thomas, 1999, p 199). 
domain embodied in the repeated actions of gathering and preparing the reeds and grasses, and proficient use of their hands to weave aesthetically attractive objects (Lamb, 1996, p 53). ${ }^{13}$

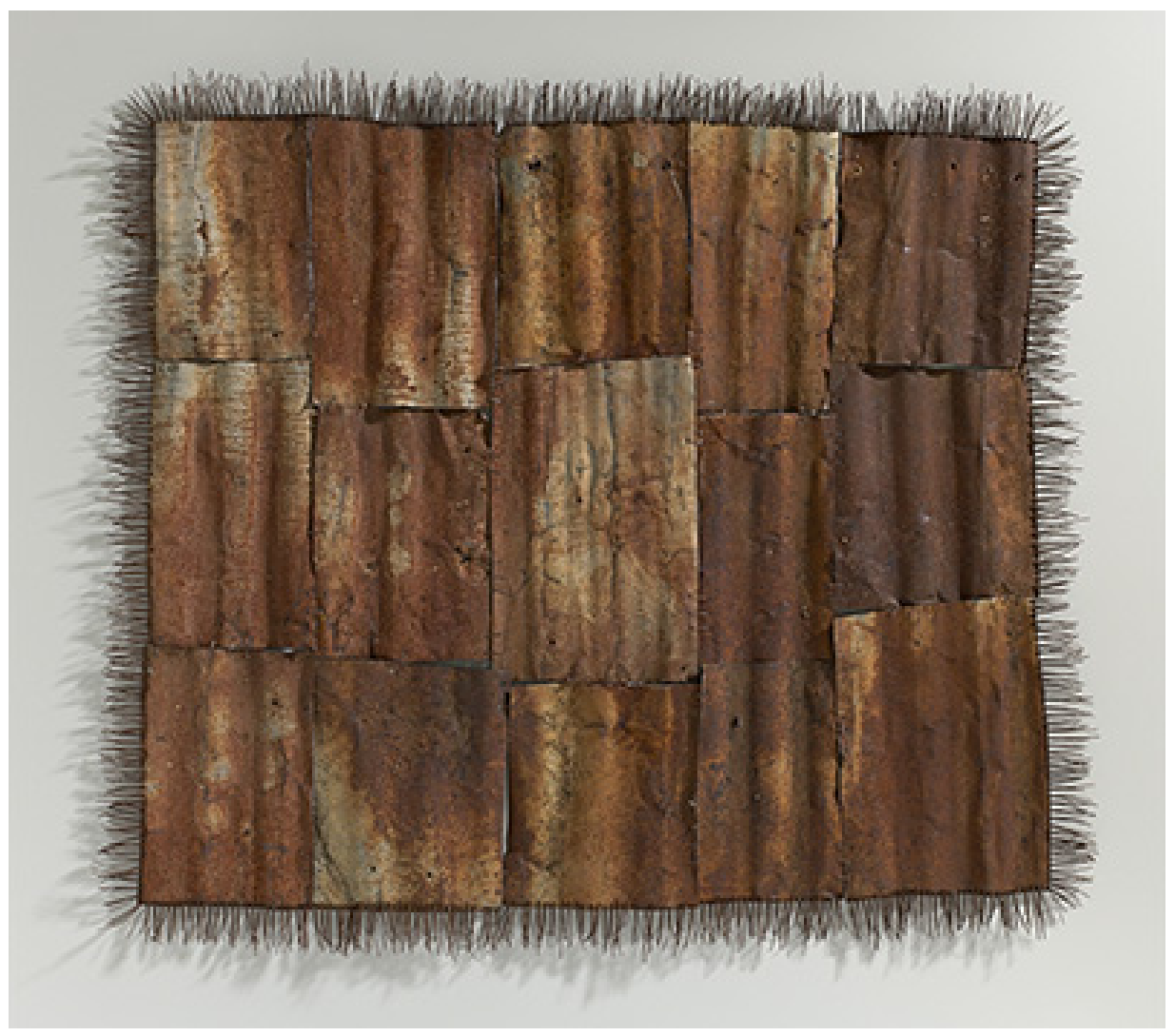

Plate 2: Lorraine Connelly-Northey, An O'possum - skin Cloak, 2005-6, rusted corrugated iron, wire, $119.5 \times 131.5 \times 5.0 \mathrm{~cm}$. Collection: National Gallery of Victoria, Melbourne. Reproduced with permission of the artist.

Thus cultural renewals may take many forms. In 1993, a workshop at the Queen Victoria Museum and Art Gallery in Launceston initiated a revival in fibre practice including the tradition of kelp water carriers unique to Tasmania. While many artists continue to make grass baskets and kelp water carriers following traditional models, Vicki West transforms the bull kelp that grows around the rugged shoreline of the island into an entirely new object. West observes that 'Lots of my work is about the survival of culture and celebrating that survival -

13 Lamb (1996, p 53) and West (2007) provide an insight into Koolmatrie's engagement with the landscape. As Yvonne Koolmatrie says, 'I'm very close to the river [the Murray] although I come from the Coorong... I couldn't survive without water. It's beautiful, it inspires me. I go through all the sites: the middens, canoe trees, the burial sites. I care for the land and the people who have been here. They've walked along the banks and pulled rushes where I'm pulling them and it just inspires me' (West, 2007, p 95). 
past, present and future' (Reynolds, 2006, p 43). Like a piece of armour, hand sewn and improvised to meet an unforeseen enemy, West's Kelp Armour (2003) apparently bears the scars of battle, shot through and shredded to ribbons. As such it is a powerful reminder of the guerilla warfare staged by Tasmanian people, effectively undoing the settler colonial myth that Aboriginal people simply melted away before the tide of civilization, or were decimated by illness, thereby whitewashing the violent battles in which Aborigines engaged. In Kelp Armour West draws creatively upon the heritage of her people but she is also operating counter- discursively, challenging authorised versions of colonial history.

An alternative political reality acknowledges that Aborigines and non-Aborigines live in a shared co-existence within a settler colonial society (Kleinert, 2002). For Wiradjuri artist Lorraine Connelly-Northey it is a relationship to be negotiated. Since 2002 she has recreated the string bags, possum skin cloaks and coolamons of an earlier era but in alternative materials, using the industrial detritus of the modern world: rusted iron, barbed wire and coils of wire. (Plate 2) In so doing she seeks to pay respect to both her mother's Indigenous connections with Country and her father's Irish descent, living on the land following a vernacular tradition of making do and improvisation. Born in Swan Hill, Lorraine Connelly-Northey initially worked in Adelaide and attended a workshop with renowned weaver Yvonne Koolmatrie. But she did not want to follow Koolmatrie by working in a traditional style of weaving and, as a Wiradjuri woman, she was not comfortable using local cummbungi grasses out of respect for the traditional owners, the Wemba Wemba (Murray, 2003). Artistically, Lorraine Connelly-Northey aims to do something distinctive and different - something innovative that really stands out (Connelly-Northey, 2009). Like Lena Yarinkura from Bolkdjam in Arnhem Land who has gained renown for her Yawkyawk (Mermaid) figures, Lorraine ConnellyNorthey wants to be innovative. The trajectory on which she is embarked is engaged in the effort of reworking discarded materials to create objects of great beauty - artworks that speak of being both black and white, taking from both to create a future imaginary.

The recent revival of possum skin cloaks by four young artists Lee Darroch, Treahna Hamm and Vicki and Debra Couzens born in the 1960s and 1970s, provides further evidence of the complexities entailed in cultural revival (Reynolds, 2005). (Plates 3 \& 4) In 1999 the four artists embarked upon a project to reproduce the two remaining possum skin cloaks in Australia held in the Museum Victoria collection: ${ }^{14}$ the Lake Condah cloak collected in 1872 and the Maiden's Punt (Echuca) cloak collected in 1853. ${ }^{15}$ With reproduction came considerable responsibility. With due respect for cultural protocols the artists engaged in consultation with elders in the relevant communities concerning the cultural significance of the cloaks, the meaning of the geometric and figurative

14 The remaining four cloaks and one engraved possum skin pelt are in collections overseas (Reynolds, 2005, p 62 fn 1).

15 The project which included possum skin cloaks and prints was funded by the National Museum of Australia. The artists named the project Tooloyn Koortakay or 'squaring the skins for rugs.' 
designs etched inside the cloaks and the story telling they generated. Even then the process of reproduction raised unforeseen problems which required adjustments and modifications. Where elements of the design were missing from the fragile cloaks, the artists embarked upon research using ethnographic records. Being a protected species, Australian possums were unavailable so the artists used New Zealand possum skins. The chemicals used to treat these skins also required poker work to be substituted for the original shell engraving and ochre. The differences between the originals and the reproductions encompassing a gap of over 150 years - are clearly evident: while the original cloaks carry a layered patina of age and ochre, the parchment-like quality and crisp designs of the new cloaks speak of a cultural future. Yet both involve a marking of skin repeating the same geometric and figurative designs that signified individual and group identity once found in body cicatrices, carved wooden artifacts and dendroglyphs (carved trees only found in the southeast) associated with burial sites.

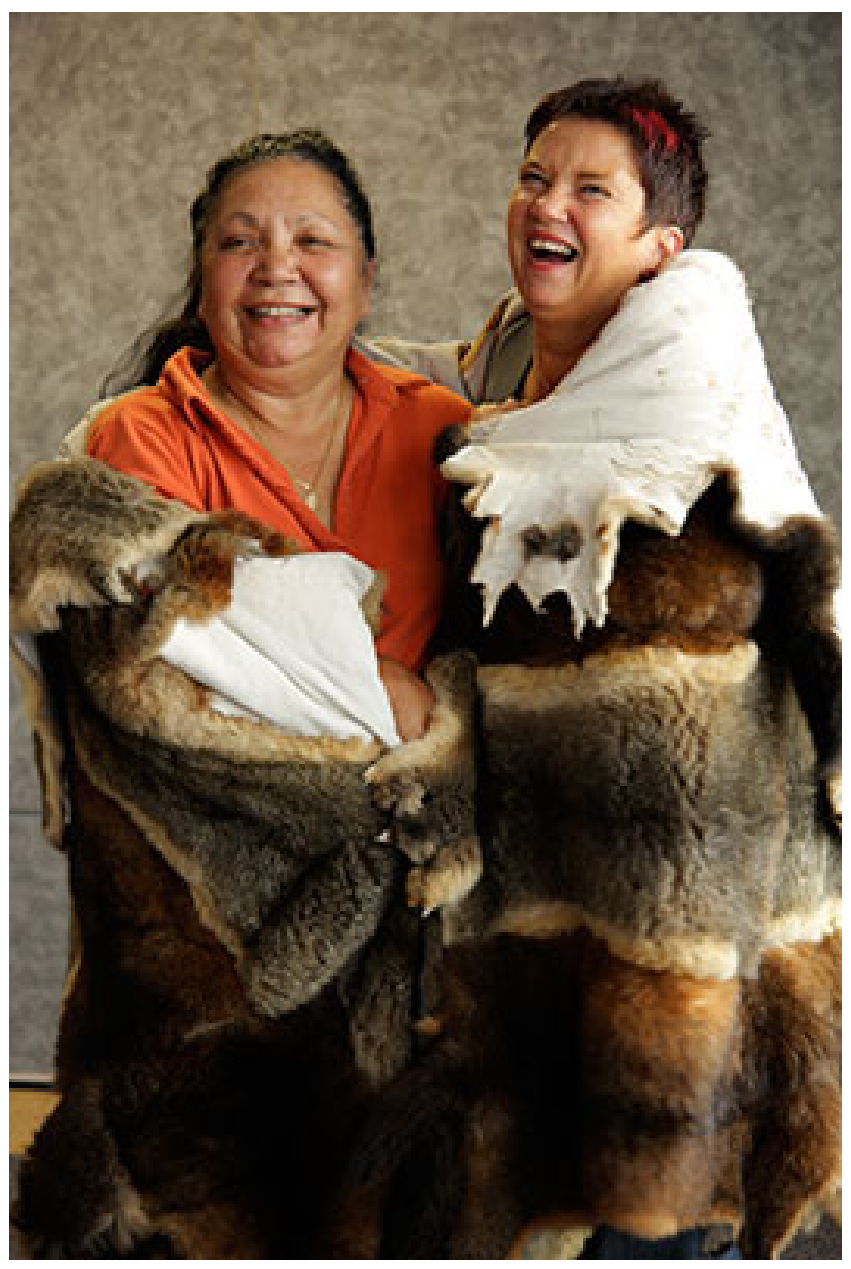

Plate 3: Aunty Matilda House and Lee Darroch, Possum Skin Cloak Workshop, Selling Yarns 2, NMA, 8 March 2009. Photograph: Elena Green. 


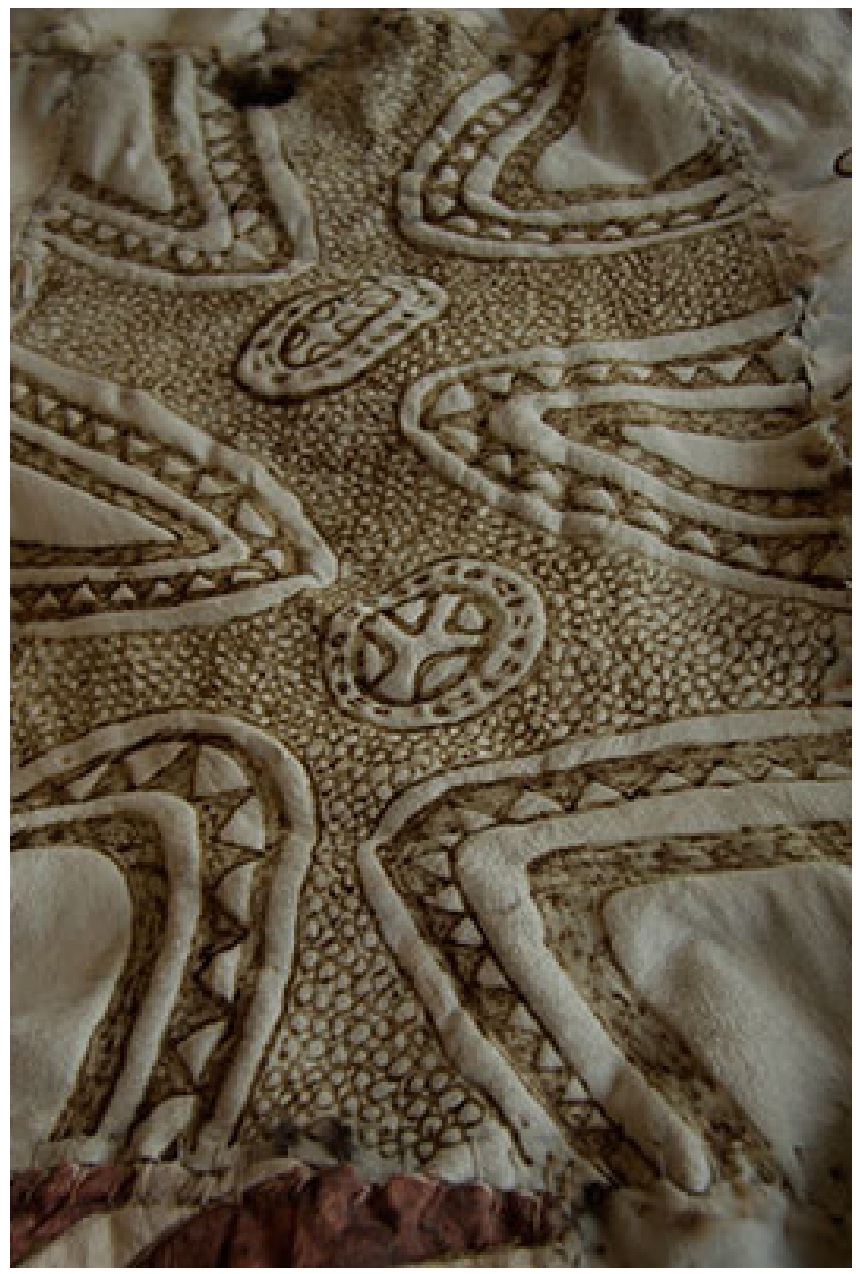

Plate 4: Detail possum skin cloak made for Festival of Pacific Arts, Lee Darroch and others featuring design by Maree Clarke, 2008. Photograph: Elena Green

For the artists concerned, the project represented a journey of self-discovery, a revival of traditions and a gift to future generations (Reynolds, 2005, pp 47-58). Yet there are differences. Lee Darroch and Treahna Hamm speak of the way the cloak-making project resignified a cultural identity denied by the 2002 findings of the Yorta Yorta Native Title claim. In the words of Treahna Hamm, 'One of the judges said the tide of history has washed away our culture. We know very well that it hasn't and we're just living proof of that' (Reynolds, 2005, p 50). ${ }^{16}$ For

16 Commonwealth legislation for Land Rights was passed in 1976 allowing some Northern Territory land to be claimed. Subsequently the Mabo judgment in 1993 recognized Aboriginal native title followed by the Wik judgment of 1996 which found that the grant of pastoral leases did not extinguish native title. However the Howard Government's 'Ten Point Plan' implemented legislation to the Native Title Act in 1998 curtailing the impact of these judgments. In the south east, militancy for land rights resulted in the return of traditional lands at Lake Tyers and Framlingham reserves in 1971 and further small parcels of land at Lake Condah in 1985. In 1993 the Yorta Yorta people filed a 
Gundidjmara artist Debra Couzens, involvement in the project 'was the start of a journey for learning about my Grandmother's Country Lake Condah way and ... [this then] took in a lot of sacred sites ....and I understood a lot more about ...the Convincing Ground' - a Gundidjmara massacre site (Reynolds, 2005, p 47). What these artists tell us is the importance of the cloak- making project as a form of action. For Indigenous writer Bruce Pascoe, the cloak- making project is 'removing some of our cataracts'(Pascoe, 2007, p 173), ensuring that the hidden history of the south east - both its rich cultural heritage and the genocide and loss of sovereignty which has taken place - is known to a younger generation of Aboriginal Australians and the wider community.

Of course such projects would not be possible without the active support of museums - including Aboriginal controlled organisations like the Koorie Heritage Trust ${ }^{17}$ and the new policies of collection and display implemented in recent years. A series of exhibitions - replete with story telling by elders, cultural performances and films -ensured that the making of the possum skin cloaks would expand into a wider domain. ${ }^{18}$

Under the auspices of Regional Arts Victoria, thirty-five cultural language groups across the state worked with the four artists to each create a possum skin cloak. When, in March 2006, community leaders wore these possum skin cloaks before a worldwide audience at the opening of the Commonwealth Games in Melbourne, they performatively used the cloaks as an expression of cultural identity. Fred Myers reminds us that this process of 'culture-making' is central to the process of 'becoming Aboriginal' where art is used as a form of action to redefine and 'gain value from the circumstances that confront them' (Myers, 1994, p 680). By engaging in a 'theatre of history' where the dialogue of cross cultural exchange occurs, such social and symbolic actions bring with them the possibility of social change.

One hundred years ago residents at Coranderrk near Melbourne participated in a somewhat similar event. In 1863, soon after the establishment of Coranderrk, a deputation led by ngurungaeta Simon Wonga attended a Governor's levee in Melbourne. On this occasion the men wore European clothes, they were wrapped in possum skin cloaks and carried spears (Attwood, 2003, pp 15-16, 19; Lydon, 2005, p 40) demonstrating that they well understood the importance of representations. Today possum skin cloaks might well be seen as fulfilling much the same roles as they have done in an earlier era: as markers of individual

\footnotetext{
land claim however in his final deliberation Justice Howard Olney rejected the claim on the grounds that 'The tide of history has indeed washed away any real acknowledgement of their traditional laws and any real observance of their traditional customs' (Broome, 2005, p 382). Following an appeal this judgment was upheld in 2002. Subsequently various cultural language groups have since negotiated title to parcels of land (Broome, 2005, pp 345-348; pp 379-382).

17 The establishment of the Koorie Heritage Trust in 1985 by Gundidjmara man Jim Berg arose out of concern for the repatriation of Aboriginal skeletal remains. The Koorie Heritage Trust now has a major collection and an exhibition space (Broome, 2005, p 386).

18 These exhibitions included: Biganga: Keeping Tradition (Barmah Forest Possum Skin Cloak) (2005-6) at Bunjilaka, Museum Victoria and Gunya Winya (Women's Cloaks) (2005) at the Koorie Heritage Trust, Melbourne.
} 
and community identity, pivotal in welcoming and repatriation ceremonies, ${ }^{19}$ in the recovery of family histories and in the intergenerational transmission of knowledge.

It is clear that cultural revivals are never just a replication of the past but a complex process of regeneration and recreation where the past is retold in the present. As such this productive activity demonstrates its transformative potential to rebuild communities and mediate with the wider public. While these artworks may fulfill multiple roles, above all they resonate as somatic objects that embody subjectivities between people and place and narratives of identity relayed across intergenerational time through long standing experience and the hand skills of creative labour.

\section{Protesting the colonial hegemony}

I turn now to the second strand of this paper, the appropriation of colonial and European clothing by Aboriginal artists working in more urbanised settings. These artists also seek to reconnect with the past as a means of asserting identity and difference, by re-establishing connections with Country and by interrogating the past to address its unresolved histories. Specifically these urban artists use colonial and European dress, in addition to Indigenous dress, to give historical resonance to past events and make explicit the power relations between Aboriginal people and the nation state.

Items of dress are a recurring feature in the work of Badtjala artist Fiona Foley. Working in printmaking, photography and installation, Foley uses the visibility politics of clothing to address issues of race and representation, gender relations and colonisation. Foley's cultural connections are to the Thoorgine people of Frazer Island and nearby Hervey Bay in Queensland. In 1987 as a young art student in Sydney she was a founding member of the Boomalli Aboriginal Artists Cooperative but in 1995 she returned to Hervey Bay to contribute to a Native Title claim and to participate in family life. The photographic series Badtjala Woman (1994) directly intervenes in discourses of Aboriginality. Foley re-presents herself as the subject matter of an archival photograph: eyes averted and naked to the waist. In one photograph she wears a reed necklace and another made of shells and she carries a twined basket, traditionally used by women for carrying food, with string handles across her forehead. Foley deliberately mimics the pose of her anonymous Badtjala forebears, dressed according to ethnographic stereotypes to represent an exotic Other. In so doing she invokes the racially inscribed body as the foundation of colonial discourses that divide primitive and civilized.

19 See, for example, the repatriation in 2003 of the DjadjaDjadja baby initially collected from a tree trunk near Charlton in 1904 together with grave goods which had been sprinkled with ochre and wrapped in a possum skin cloak and an array of Aboriginal and European items (Buckell, 2003). 


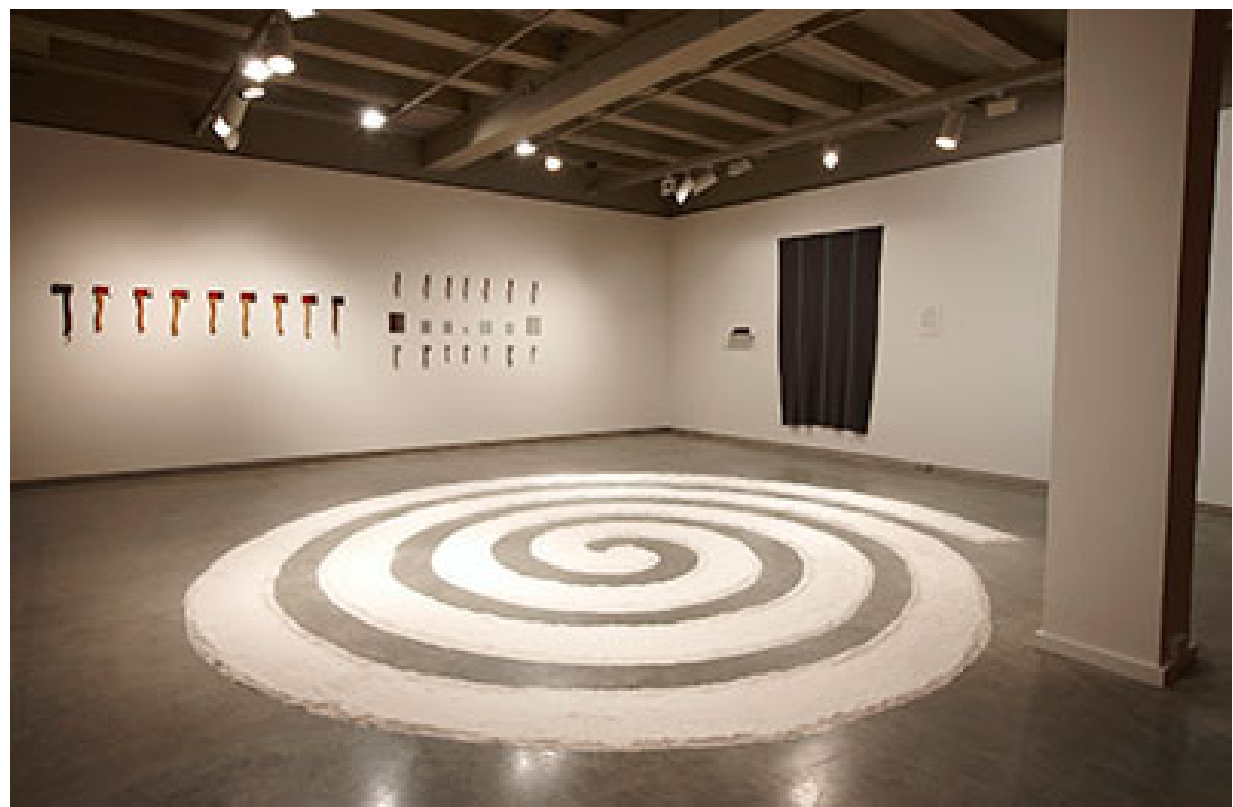

Plate 5 Fiona Foley, Land Deal, 1995, mixed media, flour, found objects, text, dimensions variable. Installation view, Museum of Contemporary Art, Sydney 2009. Image courtesy the artist, Andrew Baker Art Dealer, Brisbane and Niagara Galleries, Melbourne

Blankets are another recurring feature in Foley's installations but they come freighted with darker, historical meanings. ${ }^{20}$ From 1816 onwards government distribution of blankets and slops (basic dress of a generic kind) to Aboriginal people began under Governor Macquarie. The distribution of blankets continued throughout the south east until well into the twentieth century initially as a form of coercion and to achieve reconciliation and later as a charitable and paternalistic gesture. Once highly desired by Aborigines, when animal skins were no longer available, blankets came to be seen as a symbol of colonial generosity and a means of bargaining with government authorities. Over time, however, government-issue blankets have come to be seen more ambivalently in relation to the tensions and terror of colonial history (Maynard, 1994, pp 6566). In Foley's Land Deal (1995 )installed at the Museum of Contemporary Art, Sydney, a spiral created from 50 kilograms of flour takes centre stage. (Plate 5) Installed on the walls of the gallery are the pioneering artefacts and trinkets given in exchange for land: blankets, knives, beads, scissors, mirrors and tomahawks, objects associated with colonial welfare, the disease and death that followed European settlement and the unequal exchange of land. ${ }^{21}$ Foley is a witness to history (Healy, 2003). Specifically the installation refers to the infamous

20 In another installation, Stud Gins (2003) text printed on a row of blankets gives voice to the exploitation of Aboriginal women both on colonial frontier and in Christian missions.

21 A second related installation Lie of the Land (1977) took the form of sandstone blocks almost three metres high engraved on both sides with the names of the articles given in exchange and installed in front of Melbourne Town Hall in Swanston Street. 
Batman Treaty - the only Treaty ever offered to Aboriginal people, on 6 June 1835 between John Batman of the Port Philip Association and Kulin people of Central Victoria, and ultimately rejected by imperial and colonial governments. ${ }^{22}$ Foley includes the text of the treaty as part of the installation thereby making a 'pertinent and confronting' connection with the land claim of her particular clan group (Davidson, 1997).

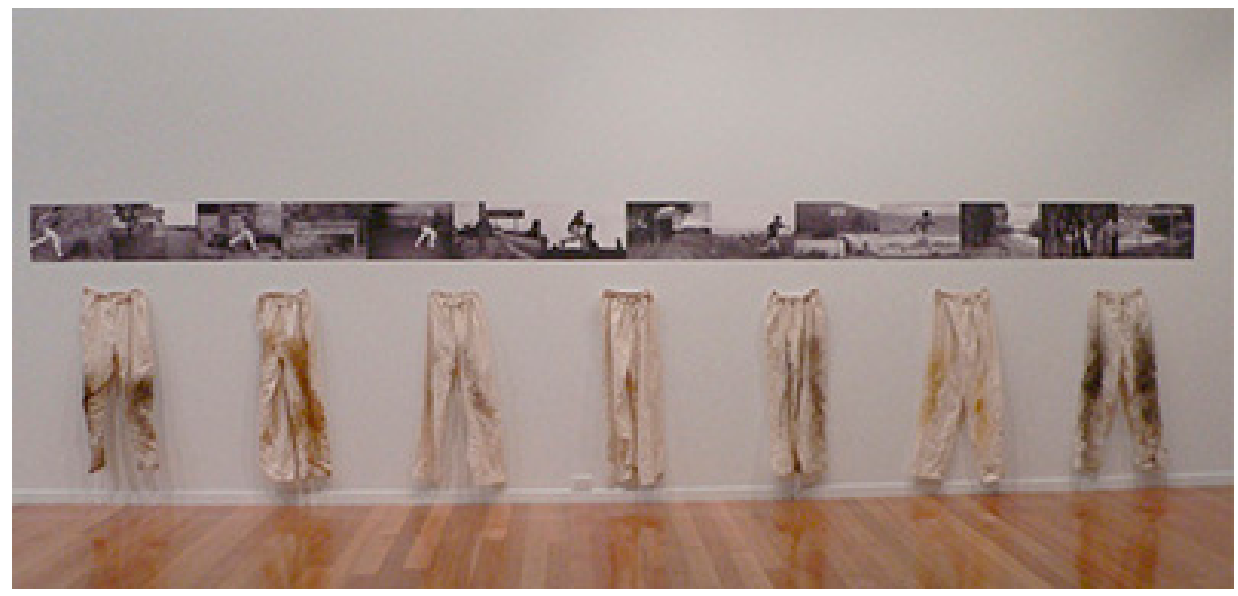

Plate 6: Julie Gough, We ran/I am. 2007, Journal of George Augustus Robinson 3 November 1830, Swan Island, North East Tasmania, calico, 14 photographs on paper, earth pigments, c. $2.0 \times 7.5 \times 0.05 \mathrm{~m}$. Photography by Craig Opie; Map of the Black Line: "Military Operations against the Aboriginal Inhabitants of Van Diemen's Land: No. 9 FIELD PLAN of MOVEMENTS OF THE MILITARY," courtesy of the Tasmania Library, State Library of Tasmania; Trousers by \#49 CWA Hobart, Collection of Devonport Regional Gallery, Reproduced with permission of the artist.

Likewise the work of Julie Gough, a Trawlwoolway Tasmanian artist and writer, addresses unresolved colonial histories. In her installation We ran/ I am (2007) (Plate 6) Gough re-enacts the 1831 'Black Line' - a genocidal event in Tasmanian history when military, police and settlers attempted to clear the settled districts of Tasmanian Aboriginal people ${ }^{23}$ (Ryan, 1996, pp 109-113, 145-159). Gough's installation includes historical maps, archival documents and photographic documentation. Text from the Journal of the Aboriginal Protector, George Augustus Robinson, written on 3 November 1830 at Swan Island, north east Tasmania, included as part of the installation, serves to remind us of the ambiguous and potentially treacherous role that clothing might fulfill in such colonial events:

22 Senior Kulin understood the Treaty not as a purchase of land but in relation to local tanderrum or welcoming ceremonies and in subsequent years the expected reciprocity took the form of feasts and gifts of brass plates, blankets, flour, rice and sugar (Broome, 2005, pp 10-11: Attwood, 2003, p 6).

23 The Black Line marked the end of the guerilla warfare waged by Aboriginal people which had successfully halted the progress of colonial settlement (Ryan, 1996, pp 110-112). 
I issued slops to all the fresh natives, gave them baubles and played the flute, and rendered them as satisfied as I could. The people all seemed satisfied at their clothes. Trousers is [sic] excellent things and confines their legs so they cannot run (Gough, 2007).

The installation documents Gough running through the landscape at seven sites on the Black Line (now overlain with modern development) replaying and reprocessing the acts of capture and escape. As part of the installation Gough includes the trousers she wore. Reenactment thus forms a key component in the installation, a metaphor for the resilience of Aboriginal Tasmanians. As Gough says, 'survival has come from an ability to swerve or deftly accommodate change' (Gough, 2007). As such, the action of running and the trousers worn are shared witnesses to past and present.

Aborigines in south eastern Australia can demonstrate a long history of involvement with petitions, walk-offs and protests in their political struggles for equality and recognition. But in the contemporary era, dress has assumed new force as an expression of identity and difference. Since the 1970s and 1980s the T-shirt has emerged as a ubiquitous item of clothing co-opted by indigenous groups worldwide as a visible assertion of individual identity and a public display of group solidarity. Margaret Maynard (2000a) points out the way in which the T-shirt could be deployed as a form of clothing in the public display of Aboriginality as an expression of pride, anger or sorrow at events such as the Black Protest Committee against the Commonwealth Games in Brisbane 1982, the celebration of the Uluru hand over in 1985, Invasion Day 1988 in Sydney in protest against the bicentennial celebrations and as an expression of mourning for Aboriginal Deaths in Custody. One memorable photograph from the Invasion Day 1988 march by artist and curator Brenda Croft depicts Michael Watson wearing face paint, a headband inscribed with 'We have survived' and a T- shirt emblazoned with the Aboriginal flag and the words 'Cook Who Cookoo'- an ironic comment on the historical figure at the centre of the bicentenary celebrations.

At the heart of identity politics lie issues of race and representation that sustain and support Aboriginal stereotypes. The knitwear created by Bidjarra artist Christian Thompson and shown as part of the Blaks Palace series in his 2002 solo exhibition during Melbourne Fashion week, refers directly to stereotypes of Aboriginality. (Plate 7) Thomson displays the jumpers in various contexts, re-housed in display cases like museum exhibits or worn with aplomb by Indigenous models such as academic Marcia Langton who shares a regional heritage with Christian Thomson (Croft, 2003, p 6, 8). Thomson directly targets the work of 1970s and 1980s designers Jenny Kee and Linda Jackson who produced fashions, printed fabrics and knitwear for their boutique Flamingo Park in Sydney (Maynard, 2000b). Using images of the kangaroo and boomerang, Thompson addresses the way in which Aboriginal art and culture is marketed as a unique symbol of Australia. However the design of the jumper with its 
strange color combinations and impossibly long sleeves - both a literal as well as metaphorical straitjacket (Croft, 2003, p 8) challenges existing ideas of Aboriginality.

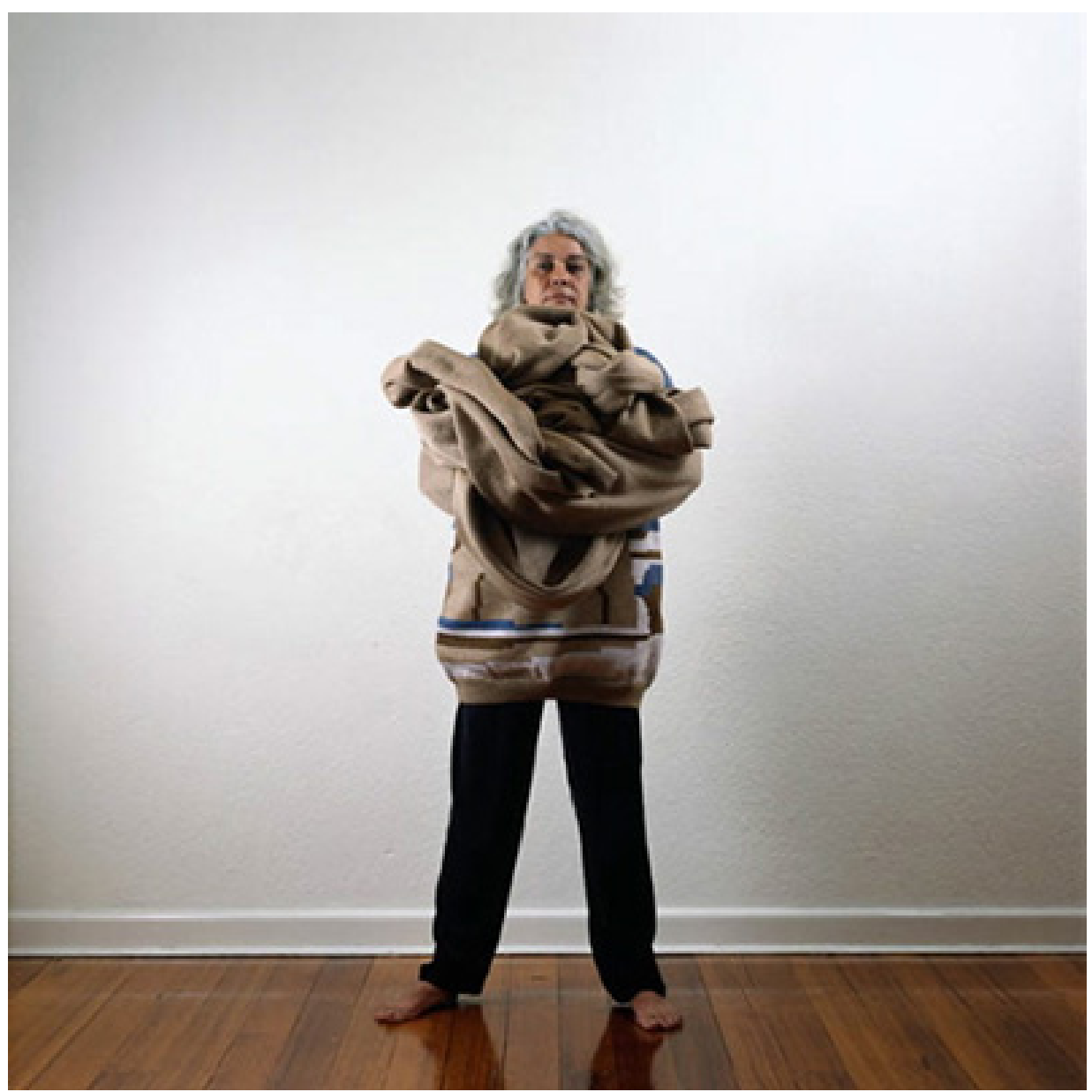

Plate 7: Christian Thomson, Untitled from the Blaks Palace series, 2002, Pegasus Print, Edition 1 of $10,55 \mathrm{~cm} \times 55 \mathrm{~cm}$. Reproduced courtesy of the artist and Gallery Gabrielle Pizzi.

As we have seen these city-based artists incorporate from both traditional Indigenous dress and European dress as subject matter for their art. These artworks, as a form of action, contribute to social and cultural sustainability by rebuilding communities, by intervening as a witness to history and by challenging representations of Aboriginality. 


\section{Conclusion}

In conclusion, what is striking is the significance of dress as a metaphor for the relationship between Aborigines and the nation state. Following two centuries of colonisation dress has assumed particular significance for Aboriginal people in south east Australia. As the subject matter of art it provides both a direct connection with an Aboriginal landscape and a means of interrogating a postcolonial world.

As somatic objects, the items of dress considered in this study are transformative as an expression of identity and difference and a means of mediating with a settler society. Viewed from within Aboriginal cosmologies grounded in continuity and innovation, the past becomes a referent for the present. That past refers to both the rich, sentient cultural heritage of an Aboriginal landscape and to the events of colonial history: the genocide, loss of sovereignty and cultural destruction for which there is little recognition in the wider community (Pascoe, 2007, p 173; Ginsburg \& Myers, 2006, p 35). In so doing, art as a form of action, contributes to social and cultural sustainability in many ways: as a means of connecting with cultural heritage; a means of addressing the unresolved histories of colonial history and a means self-performatively taking control of representations. Seen in relational and processual terms, art is a means of intervening in discourses of Aboriginality, engaged in the effort of imagining a future conceived of in moral terms (Pascoe, 2007, p 79).

In this study I have considered two discrete strands within contemporary art practice in the south east: an urban-based Aboriginal art seen as political and oppositional and a rural-based collaborative and intercultural women's fibre practice focused on cultural renewal. While each discrete strand reveals a particular character and style, my study has also revealed their many commonalities grounded in interconnected and holistic Aboriginal cosmologies. In the south east, as in other parts of Australia, art is a form of action that is central to culture-making: affirmative, mediating, exploratory and contestational.

\section{Bibliography}

Allen, L \& Lola Greeno, 2005, The south east: the importance of place and tradition in Indigenous fibre work from south-eastern Australia' in Woven forms: contemporary basket making in Australia, ed. Brian Parkes, exh. cat. Object Gallery, Sydney.

Attwood, Bain. 2003, Rights for Aborigines, Allen \& Unwin, Sydney

Broome, R. 2005, Aboriginal Victorians: A history since 1800. Allen \& Unwin Sydney.

Buckell, J. 2003, Tiny baby carries some heavy baggage,' Australian, 10 September 2003 
Connelly-Northey, L. electronic interview with the author, 1 March 2009

Craik, J. 1994, The face of fashion: cultural studies in fashion, Routledge, London.

Croft, B. 2003. Tactility: two centuries of Indigenous objects, textiles and fibre, National Gallery of Australia, Canberra.

Davidson, K, 1997. Fiona Foley: Land Deal, in In place (out of time): contemporary art in Australia, (eds) H. Morphy \& D. Elliott, Museum of Modern Art, Oxford.

Dodson, M. 2003. 'The end in the beginning: re(de)finding Aboriginality,' in Blacklines: contemporary

critical writing by Indigenous Australians (ed.) Michele Grossman, Melbourne University Press, Melbourne.

Fourmile, Henreitta. 1991. Aboriginal women - artists at last! in Aboriginal Women's Exhibition, exh. cat. Art Gallery of New South Wales, Sydney.

Genocchio, B. 2000, 'Lick my Black Art,' in Fiona Foley: Invisible voices, exh. cat Bundaberg Arts Centre. Gibson, L. 2008, 'Art, culture and ambiguity in Wilcannia, New South Wales,' Australian Journal of Anthropology, 19:3, 294313.

Greeno, L. 2006, 'Maireener: Tasmanian Aboriginal shell necklaces,' in Amanda Reynolds (ed.), Keeping culture: Aboriginal Tasmania, National Museum of Australia, Canberra.. craft + design enquiry - www.craftaustralia.org.au/cde

Griffiths, Tom. 1996, Hunters and collectors: the antiquarian imagination in Australia. Cambridge University Press, Cambridge.

Ginsburg, F \& F. Myers. 2006, 'A History of Cultural Futures,' Critique of Anthropology, Vol. 26 (1): 27-45. Glowczewski, B. 1999, 'Dynamic cosmologies and Aboriginal heritage,' in Anthropology Today, 15 (1) Feb 1999, 3-9

Gough, J. 2007, Artist's statement We ran/I am copy with the author

Grossman, E. (ed.) 2003. Introduction, Blacklines: contemporary critical writing by Indigenous Australians, Melbourne University Press, Melbourne

Hall, S. 1990. Cultural identity and diaspora, in Identity: community, culture and difference, (eds) Jonathon Rutherford, Lawrence Wishart, London.

Healy, C. 2003, Fiona Foley: Silent Witness, in Witnessing to silence: art and human rights, (eds) Caroline Turner \& Nancy Sever, Australian National University, Canberra.

Kleinert, S. 2002, What's going on?: contemporary Indigenous art from the Murray Darling region, exh. cat. Mildura Arts Centre, Mildura. 
Kleinert, S. 2010, Aboriginal dress in south east Australia, in Encyclopedia of world dress and fashion, ed. Maynard, Vol. 7, Berg, Oxford (forthcoming).

Kuper, A. 2003, The return of the native, Current Anthropology, 44: 3, 389-402.

Lydon, J. 2005, Eye contact: photographing Indigenous Australians, Duke University Press, Durham. Lamb, J. (ed.) 1996, Below the surface, exh. cat. Goulburn Regional Art Gallery, Goulburn, NSW. McCall, L. 1988, 'The European creation of 'Aboriginality' in nineteenth and early twentieth century Victoria: a study of material culture in historical documents, historical photographs and artefact collections,' Honours Thesis, LaTrobe University.

Maynard, M. 1994. Fashioned from penury: dress as cultural practice in colonial Australia Cambridge University Press, Cambridge

Maynard, M. 2000a, Indigenous dress, in The Oxford Companion to Aboriginal Art and Culture, (eds) Sylvia. Kleinert and Margo Neale, Oxford University Press, Melbourne.

Maynard, M. 2000b, Grassroots Style: Re-evaluating Australian Fashion and Aboriginal art in 1970s and 1980s, Journal of Design History, Vol. 13, No 2, 137-150.

Maynard, M. 2002, 'Blankets: the visible politics of Indigenous clothing,' in Fashioning the body politic:dress, gender and citizenship, (ed.) Wendy Parkins, Berg, Oxford.

Mellor, D \& L, Hamby, 2000. Fibre-tracks, in The Oxford Companion to Aboriginal Art and Culture, (eds) S. Kleinert \& M. Neale Oxford University Press, Melbourne.

Merlan, F. 1989, The objectification of "culture" : An aspect of current political process in Aboriginal affairs,' Anthropological Forum, 6(1), 105-116.

Morphy, H. 2008, Becoming Art: exploring cross -cultural categories, UNSW Press, Sydney.

Morphy, H. 1998, Aboriginal art, Phaidon Press, London

Morphy, H. 1992, From dull to brilliant: The aesthetics of spiritual power among the Yolngu, in Anthropology, art and aesthetics, Clarendon, Oxford, (eds) J Coote \& A. Shelton, 181-208

Murray, K. 2003, Craft unbound: making the common ground precious Craftsman House, Port Melbourne. Myers, F. 1994. Culture-making: performing Aboriginality at the Asia Society Gallery, American Ethnologist, 21 (4), 679699.

Onus, L. 1993. Southwest, southeast Australia and Tasmania, in Aratjara: art of the First Australians, exh.cat. DuMont Buchverlag, Cologne, 289-329 
Parker, R. 1984, The subversive stitch: embroidery and the making of the feminine, Women's Press, London.

Pascoe, B. 2007, Convincing ground: Learning to fall in love with your country, Aboriginal Studies Press, Canberra.

Phillips, R. \& Christopher Steiner, 1999, Unpacking culture: art and commodity in colonial and postcolonial worlds, University of California, Berkeley.

Reynolds, Amanda Jane (ed.), 2005, Wrapped in a possum skin cloak, the Toolyn Koortakay Collection in the National Museum of Australia, National Museum of Australia Press, Canberra.

Reynolds, A. (ed.), Keeping Culture: Aboriginal Tasmania, National Museum of Australia, Canberra.

Ryan, L. 1996, The Aboriginal Tasmanians, Allen \& Unwin, Sydney.

Thomas, N. 1997, 'Home décor and dance: the abstraction of Aboriginality,' in In place (out of time): contemporary art in Australia, (eds) H. Morphy \& D. Elliott, Museum of Modern Art, Oxford, 28. Thomas, N. 1999, Possessions: Indigenous art /colonial culture, Thames and Hudson, London .

West, M. 2007, Recoil: change and exchange in coiled fibre art, exh. cat. Artback Northern Territory Arts. Wood-Conroy, D. 2000, Binding the rushes: Survival of culture, The Oxford Companion to Aboriginal Art and Culture, (eds) S. Kleinert \& M. Neale Oxford University Press, Melbourne. 